\title{
The Viability of Long-Haul, Low Cost Business Models
}

Mauricio Emboaba Moreira ${ }^{1, a,{ }^{*}}$, J ohn F. O'Connell ${ }^{2, b}$ and George Williams ${ }^{2, c}$

${ }^{1}$ GOL Airlines, São Paulo, Brazil

${ }^{2}$ The Department of Air Transport, Cranfield University, Bedford, MK43 OAL, UK

\begin{abstract}
Recent events have confirmed the concerns that many within the aviation industry have held about the viability of the low cost business model for long-haul operations. This paper begins by reviewing the operating cost differences between low cost carriers (LCC) and legacy airlines in different regions of the world. This is followed by a summary of the various cost advantages of low cost carriers operating in short-haul markets. The main focus of the work, however, is a cost simulation involving the use of a Boeing 767-300 by both a LCC and a legacy carrier under varying operating assumptions. The research demonstrates that in none of the cases cited is the LCC cost advantage greater than $10 \%$.
\end{abstract}

Keywords: long-haul, low cost carrier; operating cost simulation; legacy carrier; LCC business model.

\section{INTRODUCTION}

The concept of long-haul, low cost carriers (LCC) goes as far back as 1977, when UK based Skytrain commenced services between London and New York, subsequently adding Los Angeles and Miami. It used DC-10s and pioneered some of the low cost carrier characteristics that are evident today, such as: a single class seating configuration featuring 345 seats; operated only on a point-to-point basis; while the in-flight catering was purchased. Unfortunately, Skytrain was out-priced by the competition. In 1983 a US based

\footnotetext{
a. Mauricio Emboaba Moreira is the Director of Planning and Statistics at GOL Airlines, Brazil.

${ }^{*}$ Corresponding author.

${ }^{\mathrm{b}} \mathrm{Dr}$ John (Frankie) O'Connell is a Lecturer in Airline Management at the Air Transport Department at Cranfield University where he specialises in airline strategy and marketing. He travels extensively to the world's airlines where he instructs airlines on strategy, management, branding, distribution; strategy, cost reduction; alliances; low cost carriers; deregulation; trends and customer service

${ }^{c}$ Dr George Williams was until September 2009 Reader in Airline Economics at Cranfield University. With an academic background in Transport Economics, he has extensive international lecturing and consultancy experiences and has written two books and over 50 papers and research reports all exploring the impact of deregulation on the airline industry.
} 
low cost carrier known as People Express started international operations from New York to London Gatwick, later adding Montreal and Brussels. It sold premium class seats and charged US\$3 for checked baggage, a practice that has resurfaced today. However, overexpansion and management problems led to its demise in 1987. Francis et al. (2006) provided some insight into the reasons for the demise of the long-haul, low cost carriers and explained that the regulatory constraints of international markets had impacted their competitiveness. In addition, some features that are associated with short-haul, low cost operations are less compatible with the low cost, long-haul business model, such as: seat pitch of 29", no meals, and no in-flight entertainment system. Only charter airlines and hybrid leisure companies operating a mix of scheduled and charter services have been able to operate long-haul services profitably over many years. Charter airline long-haul services have up to now been restricted to leisure destinations. These are sometimes operated for a limited number of months (seasonal) and generally with low frequencies (often only once a week). They also offer a premium class with more comfortable seating and enhanced inflight service. Almost $80 \%$ of UK long-haul charter traffic in 2007 was destined for holiday destinations in either North America (mainly Florida) or the Caribbean.

Low cost carriers have flourished on short haul markets throughout the world as their low costs give them a significant competitive advantage over the legacy carriers. This has allowed them to offer low fares, which in turn has persuaded passengers to switch from full service airlines, while at the same time stimulating new passengers who otherwise might not have travelled. Dunn (2009) reports that low cost carriers have captured $44.8 \%$ of the European market, $30.6 \%$ of the North American market, $15.4 \%$ of the Asia Pacific market and $7.2 \%$ of the South American market in 2008. Ito and Lee (2003) argued that LCC were no longer a niche segment restricted to particular geographic regions, which indicates that the next phase of their business model might be the transition into long-haul operations. Dobruszkes (2009) stated that European low cost carriers have undergone a recent evolution towards greater geographical diversification and evidence of this can be seen from Norwegian as it now serves Dubai, Turkey, Egypt and Morocco from its base at Oslo.

Many variations of the low cost carrier model exist and subsequently there are distinct differences between these carriers in areas such as: flight products, stage length, productivity, unit cost and marketing agreements. Indeed, the variety of carriers that regard themselves as LCC is now so broad, it makes categorisation extremely difficult. Some airlines in Europe for example which promote themselves as LCC, such as Air Berlin and Flybe, have 
many attributes of traditional legacy carriers, while others, such as Monarch and TUlfly, have evolved into leisure hybrids undertaking significant charter operations and growing short-haul scheduled networks. There also exist some marketing differences between LCC. In the US for example, JetBlue offers its passengers leather seats and a sophisticated inflight entertainment system that features live TV coupled with broadband connection. Southwest and Air Trans now offer seamless connectivity via a hub, while in Brazil Gol carries freight on its aircraft. While there is relatively little difference in the average seating capacity of the aircraft used by LCC around the world, there is some variation in the sectors flown. In Europe routes operated by LCC average around 1,000 kms, while in the US the equivalent figures for Southwest and J etBlue are 1,013 and $1820 \mathrm{kms}$ respectively (Table 1). The equivalent figure for Air Asia in South East Asia is 1,200 kms and for GOL in South America 913 kms.

As a result of their different operating environments and business models, LCC experience differing levels of unit cost reduction over their legacy carrier rivals. Binggeli and Pompeo (2002) calculated the unit costs of a network airline and a low cost carrier operating on intra-European routes and concluded that in 2001 there was a $63 \%$ difference. Table 2 reveals a similar unit cost difference in 2007 when BA is compared with Ryanair, while Air Asia has a comparable cost advantage over Malaysian Airlines. In the US, flight crew costs of LCC are similar to those incurred by incumbents, which reduces the cost difference for North American low cost carriers. Research by Boguslaski et al. (2004) revealed that Southwest's unit costs were some 28-51\% lower than the US major airlines in 2001. In South America, GOL's unit costs are only around $22 \%$ lower than the legacy carriers in the region.

Table 1: Operating characteristics and unit cost differences by region

\begin{tabular}{lccc}
\hline 2007 data & Average sector $(\mathrm{km})$ & $\begin{array}{c}\text { Average Aircraft } \\
\text { Capacity }\end{array}$ & $\begin{array}{c}\text { Unit cost } \\
\text { (US cents/ASK) }\end{array}$ \\
\hline $\begin{array}{l}\text { North America } \\
\text { US Airways }\end{array}$ & 1487 & 156 & 9.15 \\
Southwest & 1013 & 136 & 5.65 \\
J etBlue & 1821 & 145 & 5.17 \\
\hline Europe & 2345 & 238 & 10.60 \\
BA & 1030 & 150 & 8.53 \\
easyJ et & 1053 & 189 & 4.67 \\
Ryanair & 2248 & 238 & 7.19 \\
\hline Asia & 2644 & 310 & 6.89 \\
Malaysian & 1200 & 169 & 3.16 \\
Thai & 1057 & 177 & 9.38 \\
Air Asia & 1687 & 173 & 8.76 \\
\hline South America & 913 & 148 & 7,33 \\
TAM & & & \\
LAN & & & \\
GOL & & & \\
\hline
\end{tabular}


Table 2: Unit cost advantages of LCC by region

\begin{tabular}{lcc}
\hline 2007 data & $\begin{array}{c}\text { Unit cost } \\
\text { (US cents/ASK) }\end{array}$ & Unit cost Index \\
& 9.15 & \\
\hline US Airways & 5.65 & 100 \\
Southwest & 5.17 & 62 \\
JetBlue & 10.60 & 57 \\
\hline BA & 8.53 & 100 \\
easyj et & 4.67 & 80 \\
Ryanair & 7.19 & 44 \\
\hline Malaysian & 6.89 & 100 \\
Thai & 3.16 & 96 \\
Air Asia & 9.38 & 44 \\
\hline TAM & 8.76 & 100 \\
LAN & 7.33 & 93 \\
GOL & & 78 \\
\hline
\end{tabular}

In short-haul markets it is clear that low cost carriers can achieve unit cost levels of between $30 \%$ and $60 \%$ lower than those of legacy carriers operating similar route distances, with adjustments having been made for the differences in average stage length of each carrier. Figure 1 plots a trend line of the various unit costs for selected incumbent and low cost carriers against their average stage lengths and pegs Ryanair at around $60 \%$ below the trend line, with easyj et at $25 \%$ below. Easyj et has incorporated elements such as: serving primary airports, GDS fees and transition from Boeing to Airbus aircraft, which has altered its cost structure.

Figure 1: Influence of Stage Length on the Unit Cost of European Carriers (2006)

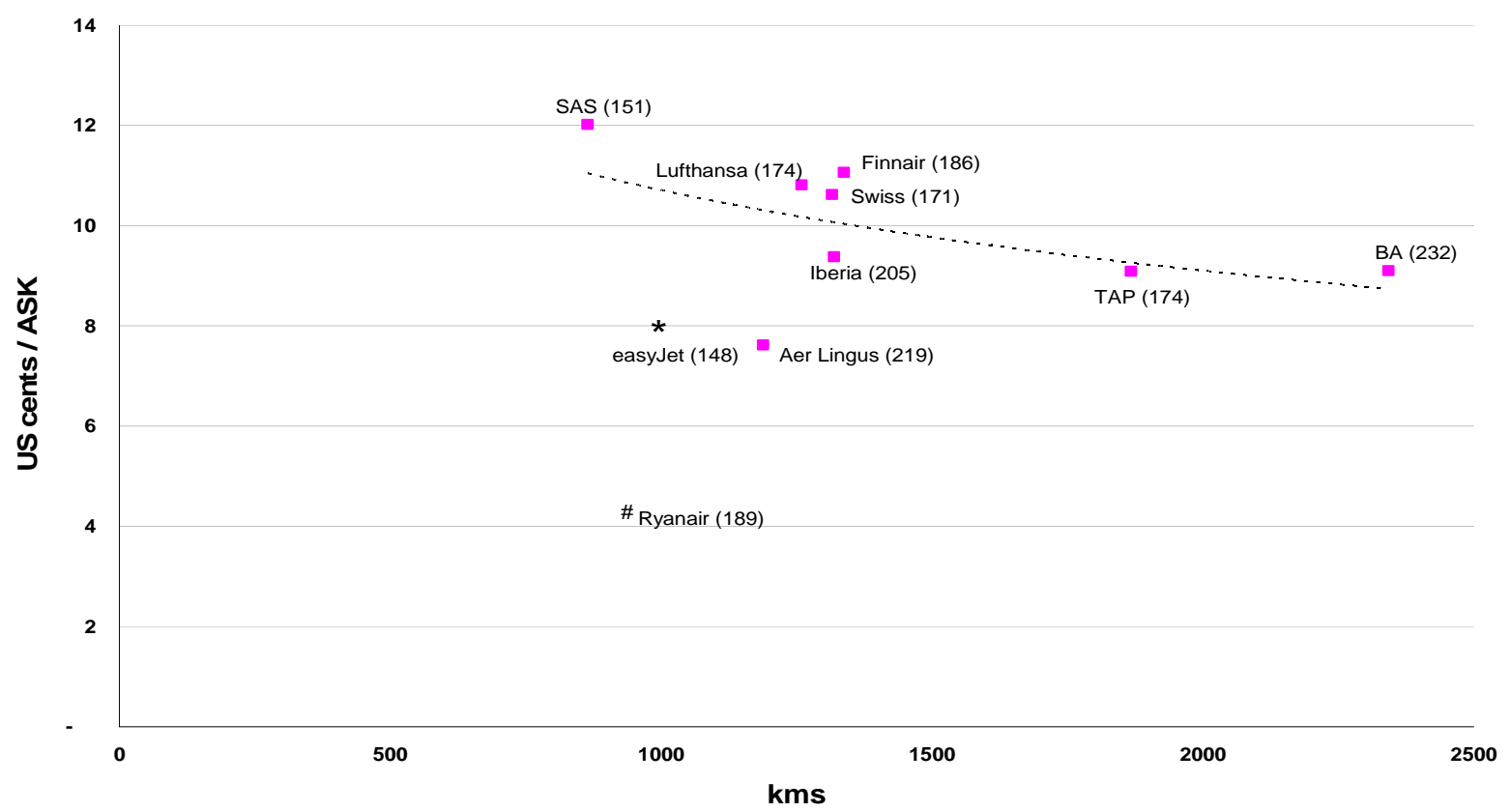




\section{SOURCES OF COST ADVANTAGE FOR LCC}

Many authors, including Button and Ison (2008), Dennis (2007), O'Connell and Williams (2005), Williams and Mason (2004), Lawton (2002), and Doganis (2001) have analysed the factors that create cost and revenue advantages for LCC and these include:

- Provision of a different range of services than legacy carriers, such as: unbundling of the flight product, serving secondary airports, etc.

- Enhanced efficiency through high aircraft utilisation and high labour productivity

- Common fleets

- Lower salaries

- Outsourcing

- Ancillary revenues

- Effective negotiations

- Single class of service

- Internet bookings and a focused website that includes third party suppliers

- Low administration costs

In Asia, aside from the cheaper labour force, further cost advantages are achieved as the region allows flights to be operated at night. This has positively impacted the operating cost of Air Asia with it recording the world's lowest unit cost per ASK in 2008 of just 2.25 US cents (Thomas, 2009). Porter (1983) was well justified in arguing that cost leadership will strategically position a company to compete very effectively.

Unit costs vary depending on the stage length flown and the number of passengers carried. There are also some elements of the cost mix that are fixed. It is therefore the case that the sources and scale of cost advantage for a LCC operating long-haul services will be different from those experienced by a LCC operating short-haul sectors. There are only a very small number of LCC operating long-haul sectors compared to the total number of LCC in operation, but the transference of the generic sources of cost advantage from short to long-haul is not a trivial task. The UK CAA also examined the scope for long-haul, no-frills LCC cost saving compared to network carriers and found that only $15 \%$ of operating costs per seat had a 'high' potential for saving, with a further $45 \%$ having 'medium' potential (CAA, 2007). Both Van der Bruggen (2008) and Francis et al. (2007) have concluded that a low cost, long-haul operation could only achieve around a $20 \%$ cost advantage over network carriers and therefore are unlikely to be able to offer fares that are more than $15 \%-20 \%$ on average lower those charged by the legacy carriers. 
In principle, the sources of cost advantage for LCC derive from the indirect elements of the cost mix and from service simplification. These may include: overhead related costs, cabin crew (a smaller number allocated), catering, distribution and passenger handling; while other important reductions in unit fixed costs may stem from the adoption of high seat density configuration. In addition, flight crews and maintenance personnel who are not members of a trade union may be paid lower salaries. Table 3 provides an indication of the likely strength of the sources of cost advantage for LCC operating short, medium and longhaul sectors. ${ }^{3}$

Table 3: Influence of stage length on the sources of LCC Cost Advantage

\begin{tabular}{lccc}
\hline LCC Cost Advantages & Short-haul & Medium haul & Long-haul \\
\hline Aircraft utilisation & $\checkmark \checkmark$ & $\checkmark$ & \\
Single class seating & $\checkmark \checkmark$ & $\checkmark$ & \\
Catering & $\checkmark \checkmark$ & $\checkmark$ & $\checkmark$ \\
Load factor & $\checkmark \checkmark$ & $\checkmark$ & $\checkmark$ \\
Distribution & $\checkmark \checkmark$ & $\checkmark \checkmark$ & \\
Secondary airports & $\checkmark \checkmark$ & $\checkmark$ & $\checkmark$ \\
Cabin crew & $\checkmark \checkmark$ & $\checkmark \checkmark$ & \\
Flight crew & $\checkmark$ & $\checkmark$ & $\checkmark$ \\
Maintenance & $\checkmark \checkmark$ & $\checkmark$ & $\checkmark$ \\
Overheads & $\checkmark \checkmark$ & $\checkmark \checkmark$ & \\
\hline
\end{tabular}

( $\checkmark \checkmark$ indicates substantial cost advantage and $\checkmark$ moderate cost saving)

Higher aircraft utilisation cannot be assumed as an attribute of LCC on long-haul sectors because, in most cases, schedules have to be compatible with traffic waves at origin and destination airports and in the case of east - west journeys time zones place a limit on departure and arrival times. Wensveen and Leick (2009) studied the long-haul, low cost business model and confirmed that high frequency connectivity to short-haul markets becomes more critical with long-haul operations since many passengers connect at one or both ends of their long-haul flights. Long-haul passenger flows therefore mostly depend heavily on traffic feed, which introduces important rigidities in the scheduling of flights.

\footnotetext{
${ }^{3}$ Short-haul is defined here as up to $1,500 \mathrm{kms}$, medium-haul between 1,501 and 3,000 kms, and long-haul $>3,000 \mathrm{kms}$.
} 
One of the principle difficulties facing many of the low cost carriers however, is that they do not have feed traffic. Some carriers have modified their business model with, for example, Southwest already interlining its own traffic through its hubs. It is also actively seeking cross-border code share and interline partners, signalling a change of emphasis over its still short-haul network (Morrell, 2008). Indeed, many LCC are now beginning to code share and these partnerships will boost feed traffic. Sobie (2009) stated that Gol, JetBlue, Jetstar, Virgin Blue and Vueling have active code share agreements in place, with Virgin Blue code sharing with Delta Air Lines, Skywest Airlines and Virgin Atlantic. Bipartisan partnerships, such as the JetBlue/Aer Lingus linkup, allows the partners to sell combination tickets that funnel two flights into a single itinerary - a strategy that has been very successful as J etBlue has received thousands of bookings through the Aer Lingus website (Ezard, 2009). Morrell (2008) stated that $25 \%$ of Oasis Hong Kong's passengers had indicated their intent to 'self connect' to and from other LCC and that it had been trying to negotiate interline agreements with these carriers before it went out of business. The potential to feed traffic to a longhaul, low cost carrier is therefore possible.

It may be the case, however, that in certain aspects LCC will incur higher unit costs than full service carriers. The higher load factors generated by LCC will directly impact the amount of fuel used per trip making this element of cost higher than that of a legacy carrier. Airport costs also may rise as passenger fees and handling become more expensive since there would be fewer flights per day over which to spread the fixed costs. In addition, smaller LCC with weaker brands will have less bargaining power with suppliers, resulting in higher costs.

\section{COST SI MULATION}

To analyse the elements of cost that vary with stage length, a simulation model involving the operation of a Boeing 767-300ER has been developed using 2007 data from the US. The assumptions adopted here are based on Boeing's Opcost Model US International rules for legacy carriers, with appropriate modifications made to take into account the operating characteristics of a typical long-haul, low cost carrier. These are as follows:

- Depreciation - 20 years to $10 \%$ residual value

- Spares investment - $4 \%$ of airframe, $16 \%$ of engine price

- Interest - 9\% interest rate, 20 year loan, 100\% debt financing

- Hull insurance $-0.25 \%$ of aircraft price 
- $\quad$ Airplane price - study price of US\$ 94 million for a Boeing 767-300ER

- $\quad$ Flight crew - $11 \%$ lower for LCC

- Cabin crew - 15\% less for LCC on account of fewer cabin crew and improved productivity

- $\quad$ Fuel - based on respective load factors and fuel price at $\$ 2.13$ per gallon

- Maintenance - labour hourly rate of $\$ 27.50$ for legacy carriers and $\$ 25.00$ for LCC

- Maintenance overheads - $225 \%$ of direct labour costs for legacy carriers, $175 \%$ for LCC

- $\quad$ Landing fees - same for both types of carrier

- Control \& Communications - same for both types of carrier

- $\quad$ Aircraft ground handling - $11 \%$ higher for LCC

- $\quad$ Seating capacity - 269 seats $(24+245)$ in a dual class layout for a Boeing 767-300ER

- Cargo load factor - $60 \%$ for containers, $25 \%$ for bulk hold

- Food costs - $40 \%$ to $60 \%$ lower for LCC

- Passenger handling - 15\% lower for LCC

- $\quad$ Revenue - passenger yields $15 \%$ lower for LCC

Three simulations of the model were undertaken.

i) The base case (A) which assumes that passenger load factors of legacy carriers is set at $77 \%$ and low cost carriers at $75 \%$. The reason for the lower load factor in the LCC case is that, by improving utilisation, LCC tend to operate out of hub waves, thereby reducing connection opportunities. On the other hand, by offering more seats at lower prices, LCC tend to attract more point-to-point traffic than legacy carriers. The result indicates a slight advantage in favour of the legacy carrier.

ii) Case (B), was run assuming a LCC passenger load factor of $80 \%$, on the basis that the legacy carrier advantage would not prevail, with demand anticipated to be more sensitive to price than in the base case. The load factor of the legacy carrier was set at $77 \%$.

iii) Case (C) was also run, on the assumption that demand would be even more sensitive to price than in the second case, driving the LCC load factor up to $85 \%$. Again the load factor of the legacy carrier remained at $77 \%$.

In all three cases, the yield of the LCC was assumed to be $15 \%$ lower than that of the legacy carrier. The cost and revenue data used to construct all of the graphs below is shown in Tables 4 and 5. 
TABLE 4

\begin{tabular}{lllllllll}
\hline \multicolumn{7}{c}{ Cash Airplane Related Operating Costs - US $\$$ cents per ASNM } \\
\hline & 2000 & 2500 & 3000 & 3500 & 4000 & 4500 & 5000 & 5500 \\
Legacy & 5.90 & 5.81 & 5.74 & 5.76 & 5.82 & 5.89 & 5.98 & 6.08 \\
LCC 75\% & 5.54 & 5.46 & 5.40 & 5.42 & 5.47 & 5.54 & 5.62 & 5.71 \\
LCC 80\% & 5.56 & 5.48 & 5.42 & 5.44 & 5.49 & 5.56 & 5.64 & 5.74 \\
LCC 85\% & 5.58 & 5.50 & 5.44 & 5.46 & 5.52 & 5.58 & 5.67 & 5.76 \\
\hline
\end{tabular}

\begin{tabular}{lllllllll}
\hline \multicolumn{7}{c}{ Airplane Related Operating Costs } & - US\$ cents per ASNM \\
\hline & 2000 & 2500 & 3000 & 3500 & 4000 & 4500 & 5000 & 5500 \\
Legacy & 8.36 & 8.08 & 7.89 & 7.80 & 7.76 & 7.75 & 7.78 & 7.83 \\
LCC 75\% & 7.82 & 7.58 & 7.42 & 7.36 & 7.37 & 7.36 & 7.38 & 7.43 \\
LCC 80\% & 7.84 & 7.60 & 7.45 & 7.38 & 7.39 & 7.38 & 7.41 & 7.45 \\
LCC 85\% & 7.86 & 7.62 & 7.47 & 7.41 & 7.41 & 7.40 & 7.43 & 7.48 \\
\hline
\end{tabular}

\begin{tabular}{lcrrrrrrr}
\hline \multicolumn{8}{c}{ Total Operating Costs } & - US\$ cents per ASNM \\
\hline & 2000 & 2500 & 3000 & 3500 & 4000 & 4500 & 5000 & 5500 \\
Legacy & 11.37 & 10.79 & 10.38 & 10.13 & 9.98 & 9.87 & 9.82 & 9.80 \\
LCC 75\% & 10.33 & 9.84 & 9.52 & 9.34 & 9.26 & 9.18 & 9.14 & 9.13 \\
LCC 80\% & 10.45 & 9.95 & 9.63 & 9.44 & 9.35 & 9.27 & 9.23 & 9.22 \\
LCC 85\% & 10.58 & 10.07 & 9.73 & 9.54 & 9.45 & 9.36 & 9.32 & 9.30 \\
\hline
\end{tabular}

\begin{tabular}{lccrrrrrr}
\hline \multicolumn{7}{c}{ Revenue Per Available Seat-N.M. (RASM) - US\$ cents } \\
\hline & 2000 & 2500 & 3000 & 3500 & 4000 & 4500 & 5000 & 5500 \\
Legacy & 12.45 & 11.84 & 11.40 & 11.06 & 10.77 & 10.53 & 10.31 & 10.12 \\
LCC 75\% & 10.58 & 10.06 & 9.68 & 9.38 & 9.14 & 8.94 & 8.75 & 8.59 \\
LCC 80\% & 11.14 & 10.59 & 10.20 & 9.89 & 9.63 & 9.42 & 9.22 & 9.05 \\
LCC 85\% & 11.77 & 11.19 & 10.77 & 10.45 & 10.18 & 9.95 & 9.75 & 9.56 \\
\hline
\end{tabular}

\begin{tabular}{lrrrrrrrr}
\hline \multicolumn{6}{c}{ Profitability Comparison - Legacy vs. Long-haul Low Cost carriers - Net profit (Loss) per Trip - US Dollars } \\
\hline & 2000 & 2500 & 3000 & 3500 & 4000 & 4500 & 5000 & 5500 \\
Legacy & $5,792.00$ & $7,079.00$ & $8,237.00$ & $8,684.00$ & $8,563.00$ & $7,950.00$ & $6,653.00$ & $4,739.00$ \\
LCC 75\% & $1,372.00$ & $1,453.00$ & $1,251.00$ & 398.00 & $(1,237.00)$ & $(2,952.00)$ & $(5,226.00)$ & $(8,080.00)$ \\
LCC 80\% & $3,715.00$ & $4,302.00$ & $4,590.00$ & $4,215.00$ & $3,041.00$ & $1,774.00$ & $(63.00)$ & $(2,495.00)$ \\
LCC 85\% & $6,400.00$ & $7,558.00$ & $8,401.00$ & $8,565.00$ & $7,914.00$ & $7,153.00$ & $5,811.00$ & $3,857.00$ \\
\hline
\end{tabular}


TABLE 5

\begin{tabular}{lcccccccr}
\hline \multicolumn{7}{c}{ Cash Airplane Related Operating Costs per ASNM - Legacy carrier = 100,0 } \\
\hline Legacy & 2000 & 2500 & 3000 & 3500 & 4000 & 4500 & 5000 & 5500 \\
LCC 75\% & 100.0 & 100.0 & 100.0 & 100.0 & 100.0 & 100.0 & 100.0 & 100.0 \\
LCC 80\% & 94.0 & 94.0 & 94.1 & 94.1 & 94.0 & 94.1 & 94.0 & 93.9 \\
LCC 85\% & 94.3 & 94.3 & 94.4 & 94.4 & 94.4 & 94.4 & 94.4 & 94.3 \\
\hline
\end{tabular}

\begin{tabular}{lrrrrrrrr}
\hline \multicolumn{7}{c}{ Airplane Related Operating Costs per ASNM - Legacy carrier = 100,0 } \\
\hline & 2000 & 2500 & 3000 & 3500 & 4000 & 4500 & 5000 & 5500 \\
Legacy & 100.0 & 100.0 & 100.0 & 100.0 & 100.0 & 100.0 & 100.0 & 100.0 \\
LCC 75\% & 93.6 & 93.8 & 94.1 & 94.4 & 95.0 & 94.9 & 94.9 & 94.9 \\
LCC 80\% & 93.8 & 94.0 & 94.4 & 94.7 & 95.2 & 95.2 & 95.2 & 95.2 \\
LCC 85\% & 94.0 & 94.2 & 94.7 & 95.0 & 95.5 & 95.5 & 95.5 & 95.5 \\
\hline
\end{tabular}

\begin{tabular}{lrrrrrrrr}
\hline \multicolumn{7}{c}{ Total Operating Costs } & per ASNM - Legacy carrier & 100,0 \\
\hline & 2000 & 2500 & 3000 & 3500 & 4000 & 4500 & 5000 & 5500 \\
Legacy & 100.0 & 100.0 & 100.0 & 100.0 & 100.0 & 100.0 & 100.0 & 100.0 \\
LCC 75\% & 90.8 & 91.2 & 91.7 & 92.2 & 92.8 & 93.0 & 93.1 & 93.2 \\
LCC 80\% & 91.9 & 92.3 & 92.8 & 93.2 & 93.7 & 93.9 & 94.0 & 94.1 \\
LCC 85\% & 93.0 & 93.3 & 93.8 & 94.1 & 94.7 & 94.8 & 94.9 & 94.9 \\
\hline
\end{tabular}

\begin{tabular}{lccccrrrr}
\hline \multicolumn{7}{c}{ Revenue Per Available Seat-N.M. (RASM) - Legacy carrier = 100,0 } \\
\hline & 2000 & 2500 & 3000 & 3500 & 4000 & 4500 & 5000 & 5500 \\
Legacy & 100.0 & 100.0 & 100.0 & 100.0 & 100.0 & 100.0 & 100.0 & 100.0 \\
LCC 75\% & 85.0 & 85.0 & 84.9 & 84.8 & 84.9 & 84.9 & 84.9 & 84.9 \\
LCC 80\% & 89.5 & 89.4 & 89.5 & 89.4 & 89.4 & 89.5 & 89.4 & 89.4 \\
LCC 85\% & 94.5 & 94.5 & 94.5 & 94.5 & 94.5 & 94.5 & 94.6 & 94.5 \\
\hline
\end{tabular}

\begin{tabular}{|c|c|c|c|c|c|c|c|c|}
\hline & 2000 & 2500 & 3000 & 3500 & 4000 & 4500 & 5000 & 5500 \\
\hline Legacy & 100.0 & 100.0 & 100.0 & 100.0 & 100.0 & 100.0 & 100.0 & 100.0 \\
\hline LCC 75\% & 23.7 & 20.5 & 15.2 & 4.6 & (14.4) & (37.1) & $(78.6)$ & (170.5) \\
\hline LCC $80 \%$ & 64.1 & 60.8 & 55.7 & 48.5 & 35.5 & 22.3 & $(0.9)$ & (52.6) \\
\hline LCC 85\% & 110.5 & 106.8 & 102.0 & 98.6 & 92.4 & 90.0 & 87.3 & 81.4 \\
\hline
\end{tabular}

\subsection{RESULTS OF THE BASE CASE (LCC LOAD FACTOR OF 75\% )}

One of the most important cost drivers for an airline is its aircraft utilisation rate. Although in short-haul operations LCC obtain higher utilisation rates than legacy carriers, their advantage tends to reduce as average stage length increases. For example, in Europe LCC easy] et achieved 11.1 hours daily utilisation in 2006 from its fleet of Airbus 319 aircraft, while the average obtained by BA for the same aircraft type in its fleet was 8.7 hours. The experience with long-haul aircraft reveals comparatively little difference however. While BA's fleet of 57 Boeing 747-400 aircraft averaged 13.1 flying hours daily in 2007, a long-haul, low cost carrier named Zoom UK obtained 14.8 hours from its one Boeing 767-300. The reasons 
for this are that LCC have lower turnaround times due to their simplified loading and unloading processes, and fly mostly from uncongested secondary airports. However, as stage length increases, the proportion of time on the ground of total trip time reduces, making the ground time advantage progressively less relevant. In addition, long-haul operations, particularly east-west flights that cross many different time zones, are not constrained by the working day limitations evident in many short-haul markets.

Figure 2 results from the assumption that both legacy carriers and long-haul LCC are likely to operate from and to major hubs in North America and Europe, with similar operating time windows (curfew hours and departure/arrival times limited by time zone considerations) using wide-body aircraft but with a 15 minutes faster turnaround for LCC. While LCC are likely to achieve better utilization rates operating shorter trip lengths, this advantage is negated for longer trips, as is shown below.

Figure 2: Aircraft Utilization Profile

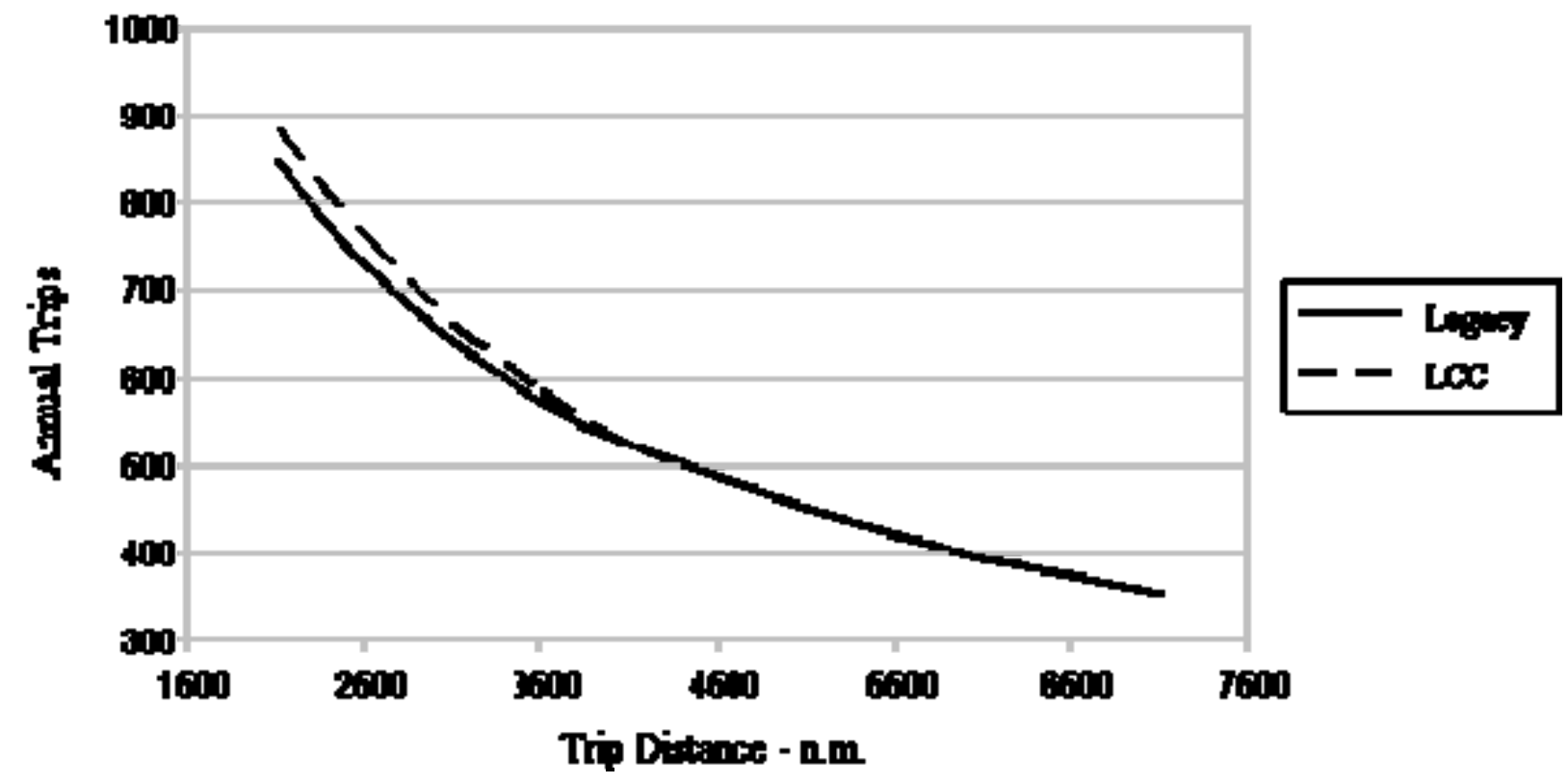

Figure 3 shows the aircraft related cash operating costs per Available Seat Mile (ASM) versus the trip distance for both legacy carriers and LCC. These are cash costs that are highly visible and are expenses that must be paid and include fuel, flight and cabin crew, maintenance, landing charges, ATC and communications, aircraft handling, ground property and equipment maintenance and overheads, and APU fuel burn on the ground. The ultimate distance where there are greatest economies of scale in relation to such costs is achieved at around 3,000 nautical miles. 
Figure 3: Aircraft Related Cash Operating Costs per ASM

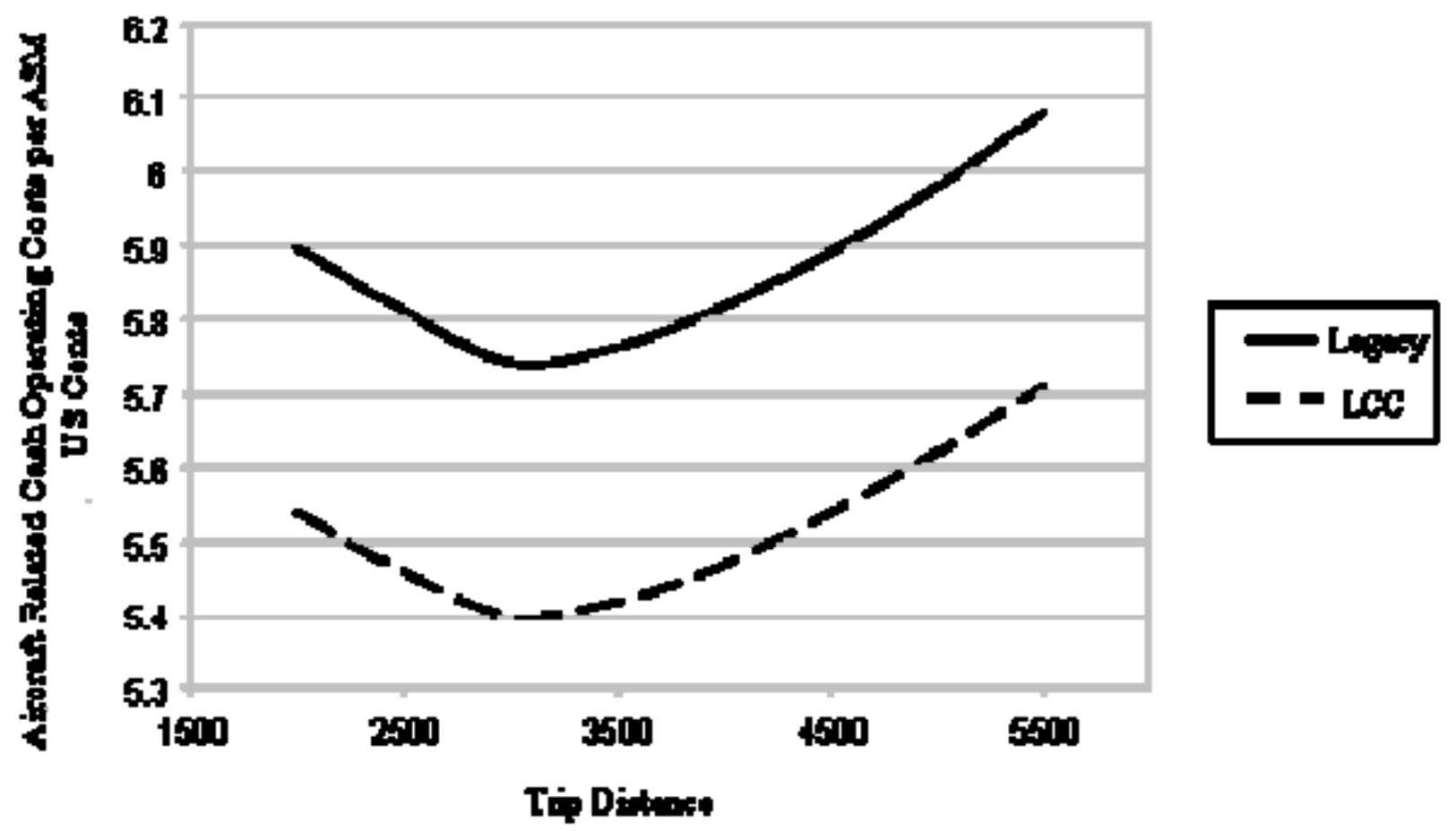

Figure 4 adds on other aircraft related operating costs that are not so visible and are estimated in the profit and loss account and include depreciation, interest and hull insurance, versus trip distance. Figure 4 includes the aircraft related cash operating costs calculated in Figure 3 above. As expected, the LCC curve is consistently below that of the legacy carrier.

Figure 4: Aircraft Related Operating Costs per ASM

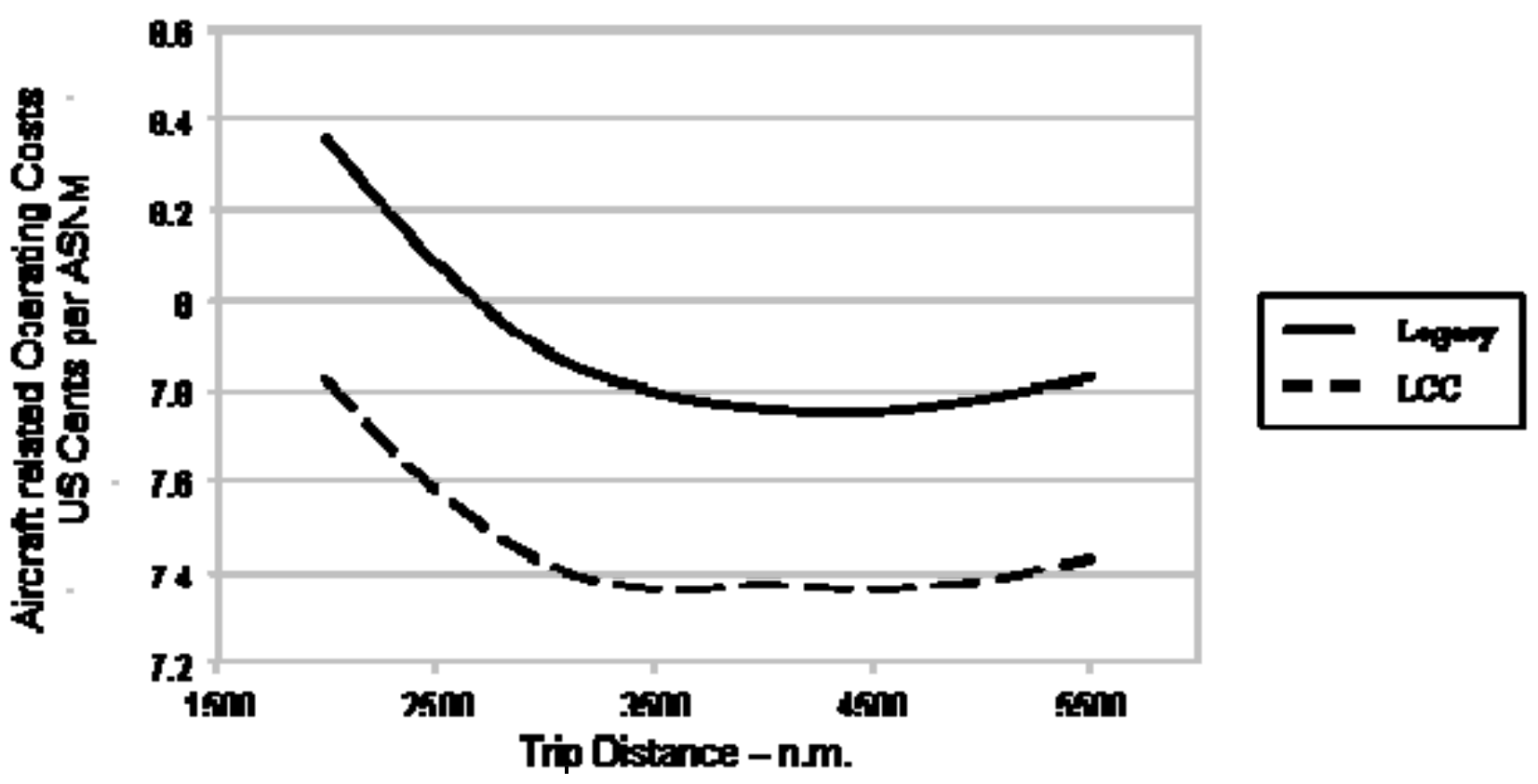


Figure 5 shows the total operating costs per ASM curves for the two carrier types. These costs include aircraft related operating costs plus passenger, cargo and system related elements. Once again, as expected, the LCC curve is consistently below that of the legacy carrier. Figure 6 shows the revenue per available seat-mile (RASM) versus trip distance for the two carrier types. As may be seen, under the base case assumptions, the legacy carrier curve is consistently above that of the LCC curve. The legacy carrier has a greater mix of high and low fare passengers as their in-flight products accommodate business class passengers and also carry cargo which increases the overall revenue per departure. This advantage of the legacy carrier does not prevail in every situation however, although the results shown here correspond to the general rule.

Figure 5: Total Operating Costs per ASM

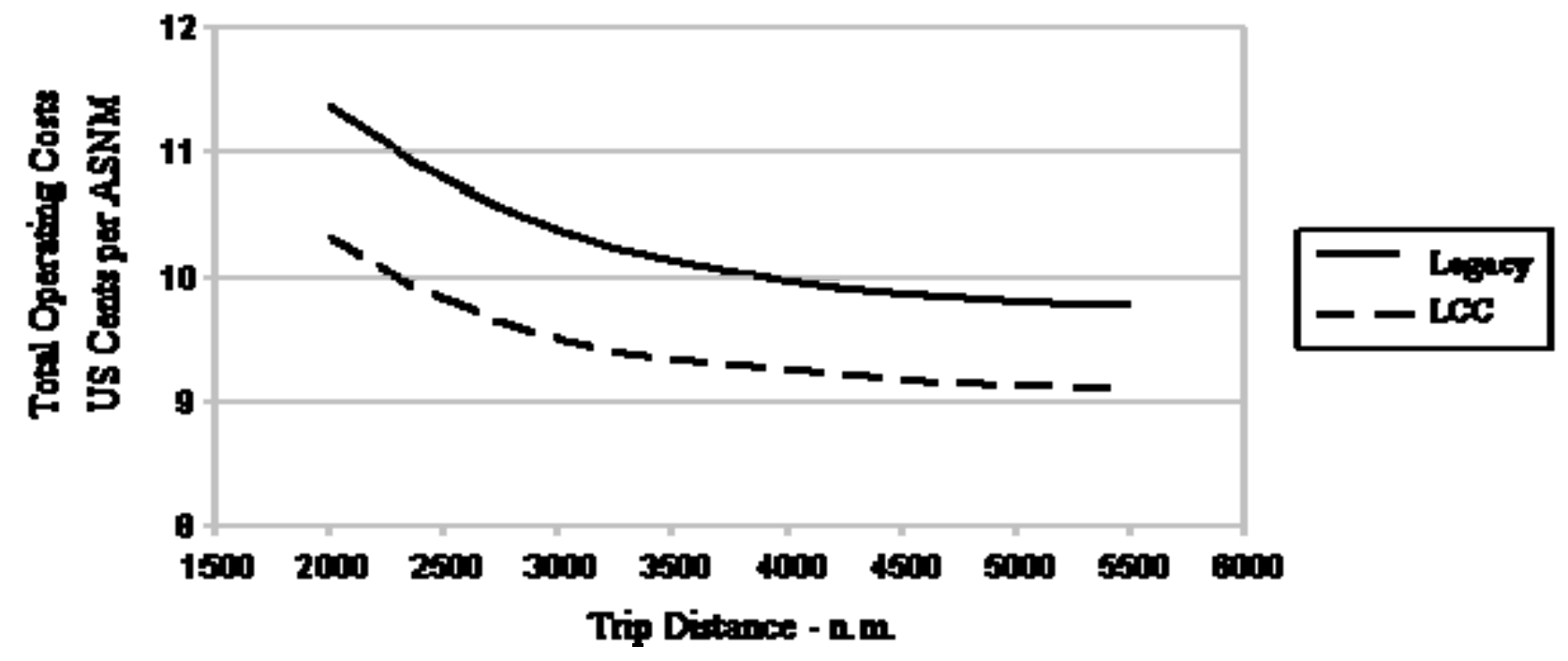

Finally, Figure 7 provides a profitability comparison between the legacy airline and the longhaul low cost carrier, demonstrating that, under the above assumptions, the former exhibits a superior performance at any of the trip distances considered. This mostly results from the conservative assumption made in respect of the LCC's load factor. While the LCC's revenue is on average $15 \%$ below that of the legacy carrier, its corresponding costs are only around $9 \%$ lower. With a load factor of $75 \%$, the long-haul, low cost carrier is only marginally profitable on sector lengths of around 3,500 nautical miles and beyond this distance, it quickly begins to financially underperform. 
Figure 6: Revenue per ASM
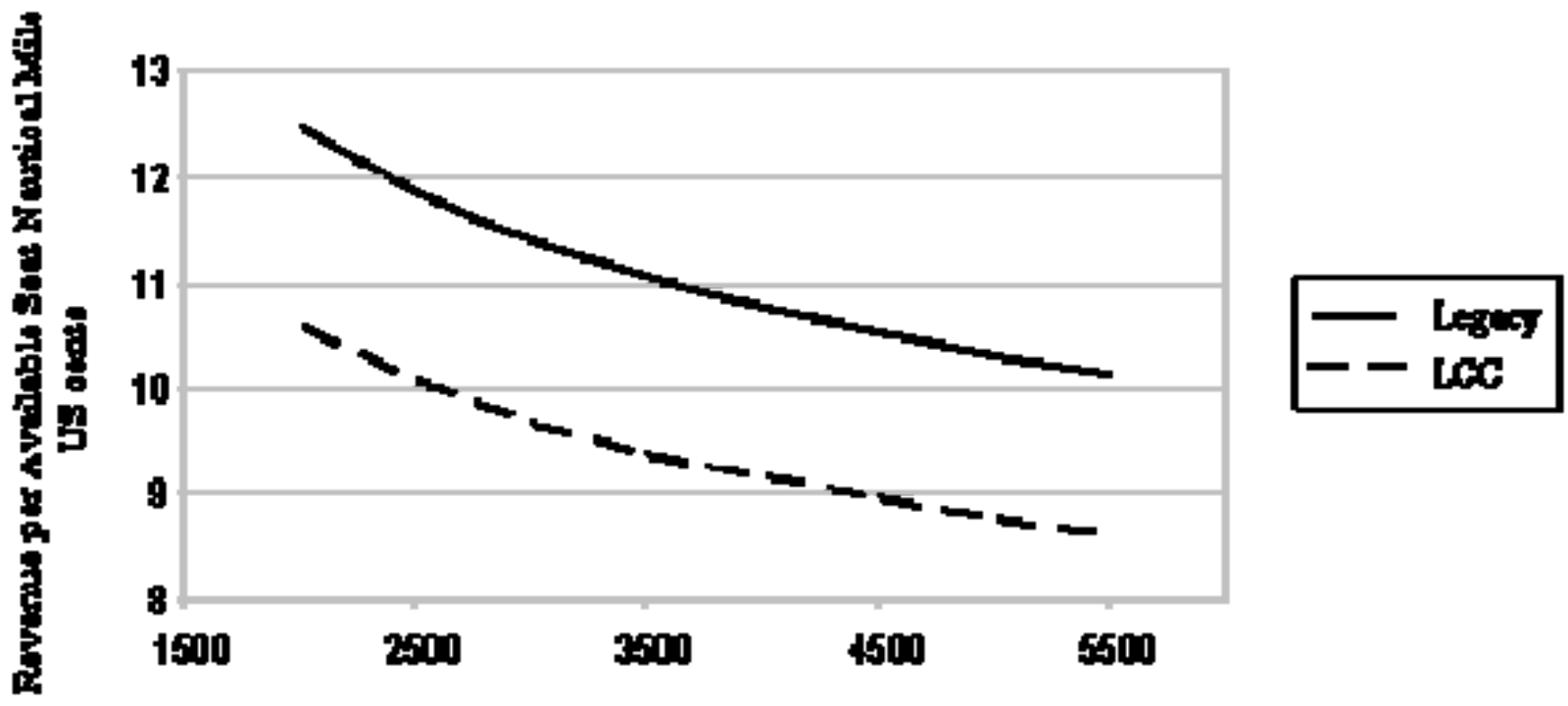

Tip Ditunes - nn

Figure 7: Profitability Comparison: Legacy carrier versus long-haul LCC

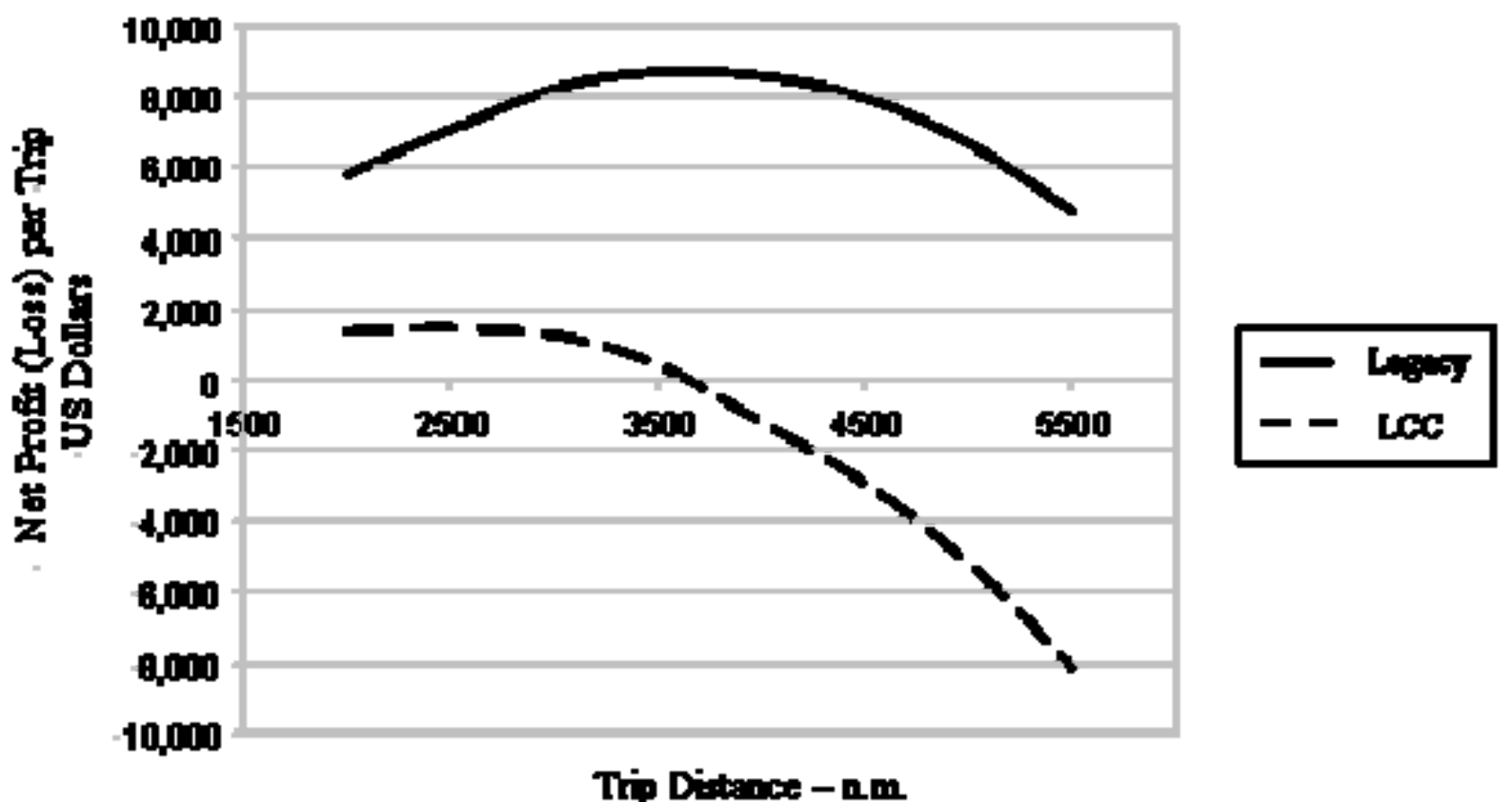

\subsection{RESULTS OF CASE B (LCC LOAD FACTOR OF $80 \%$ )}

This case was run on the assumption that demand would be more sensitive to price than was assumed in the base case. In this instance, with the LCC fare $15 \%$ below that of the legacy carrier, the former produces a load factor of $80 \%$ and the legacy carrier one of $77 \%$. The aircraft utilisation profile is the same as in the base case. The resulting cost and 
revenue curves are shown in Figures 8, 9, 10 and 11 below. As is apparent, the LCC's cost curves at $80 \%$ load factor are not exactly the same as those in the base case because, by transporting more passengers, costs will be higher, even though by a relatively small amount.

Figure 8: Aircraft Related Cash Operating Costs per ASM
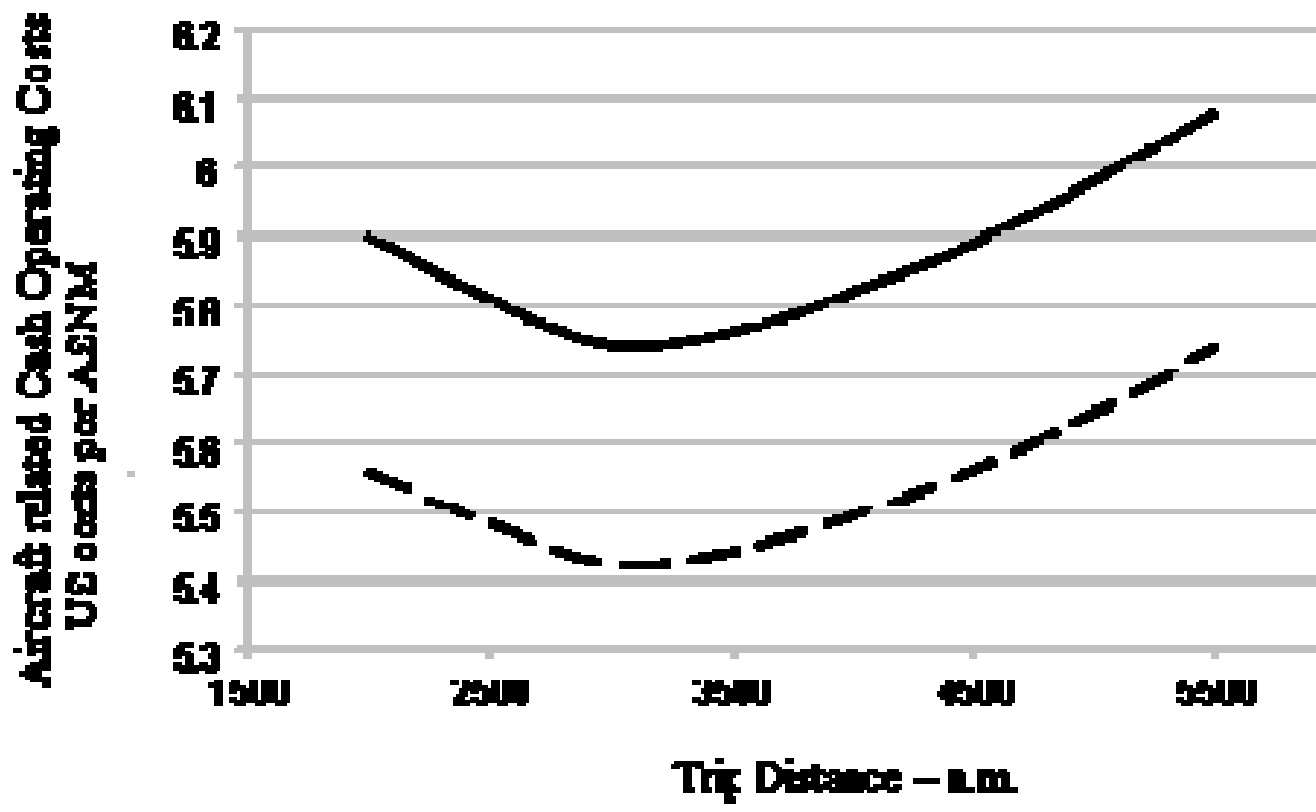

Figure 9: Aircraft Related Operating Costs per ASM
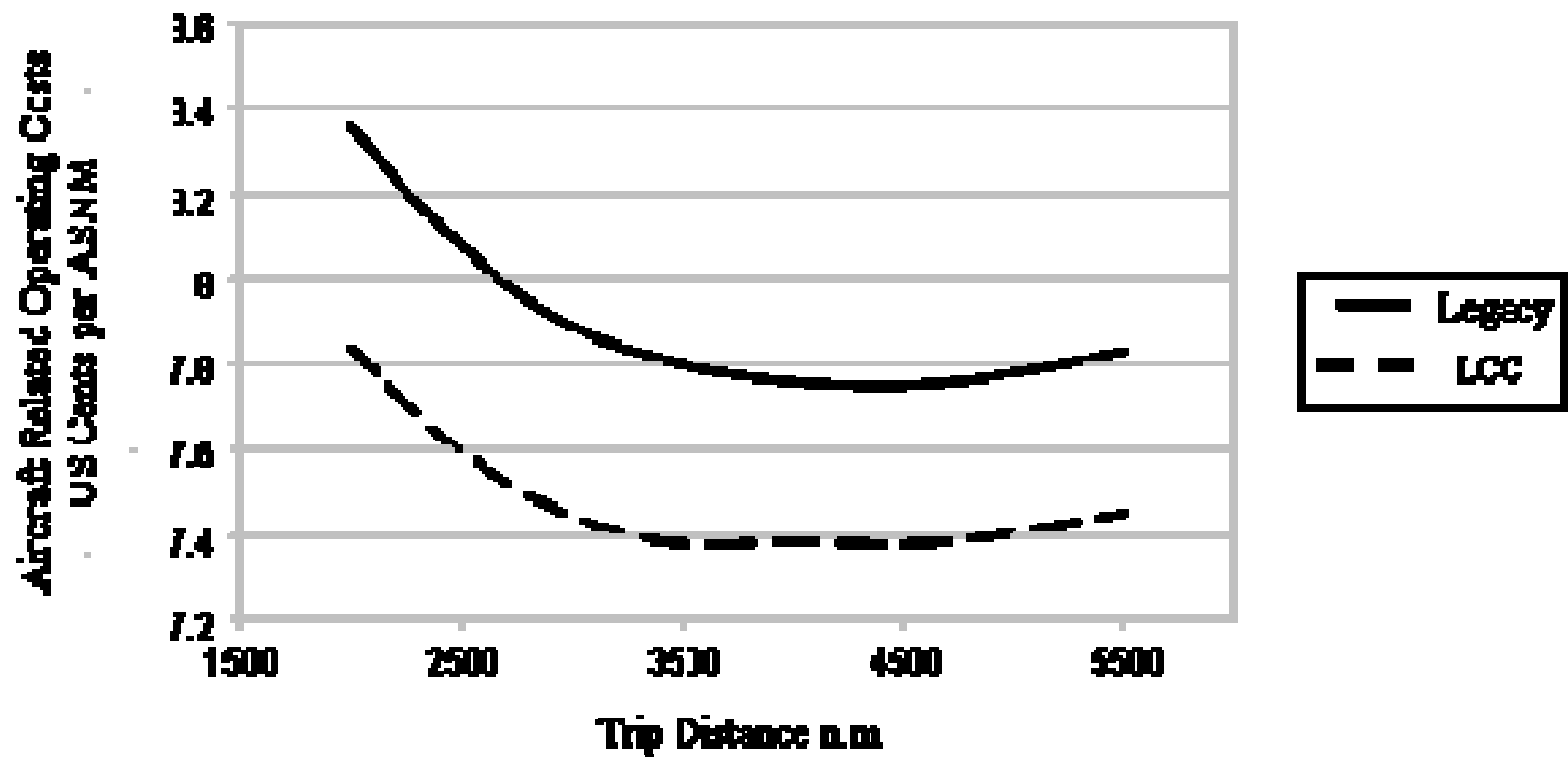
Figure 10: Total Operating Costs per ASM

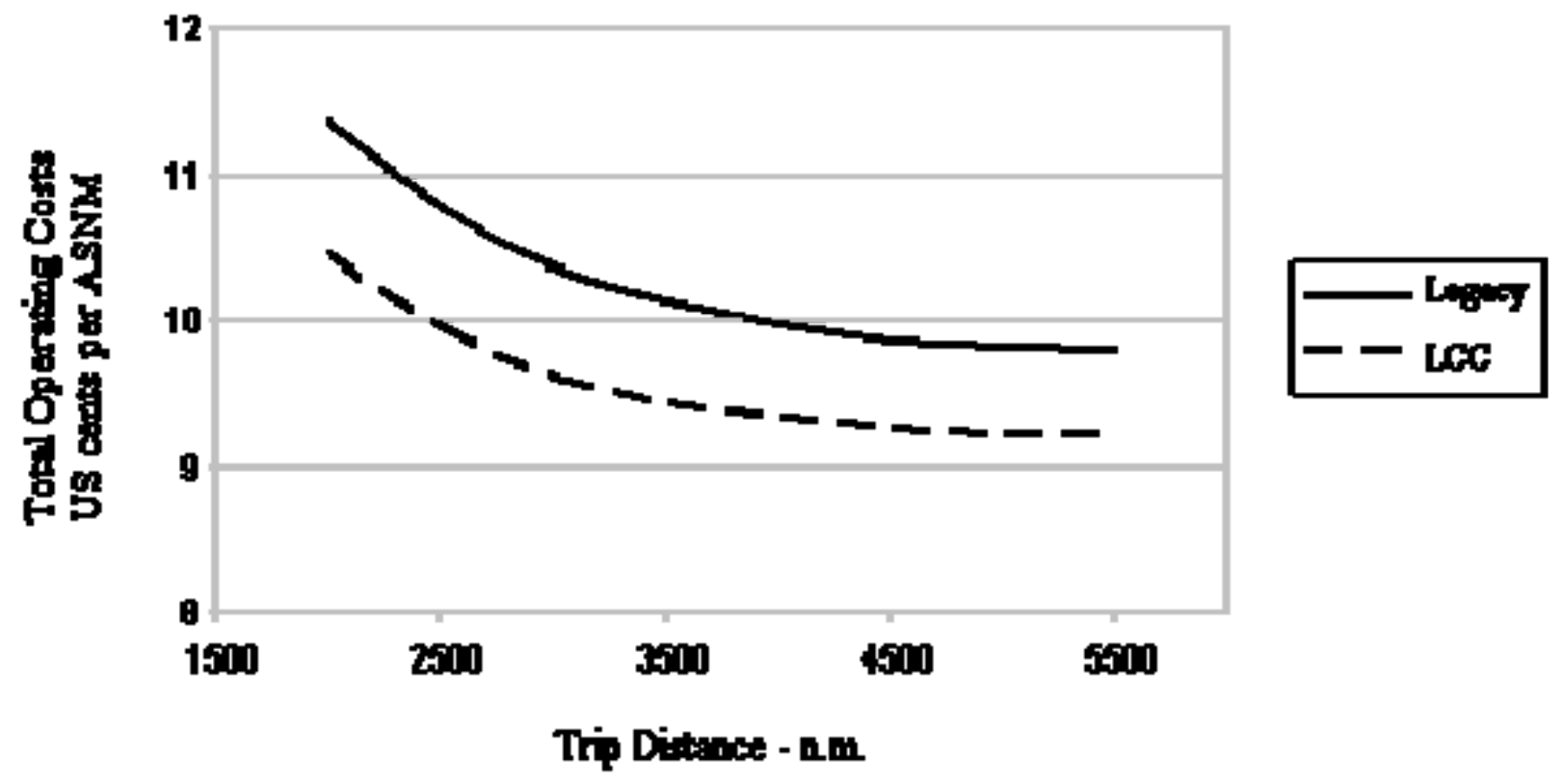

Figure 11: Revenue per ASM (RASM)

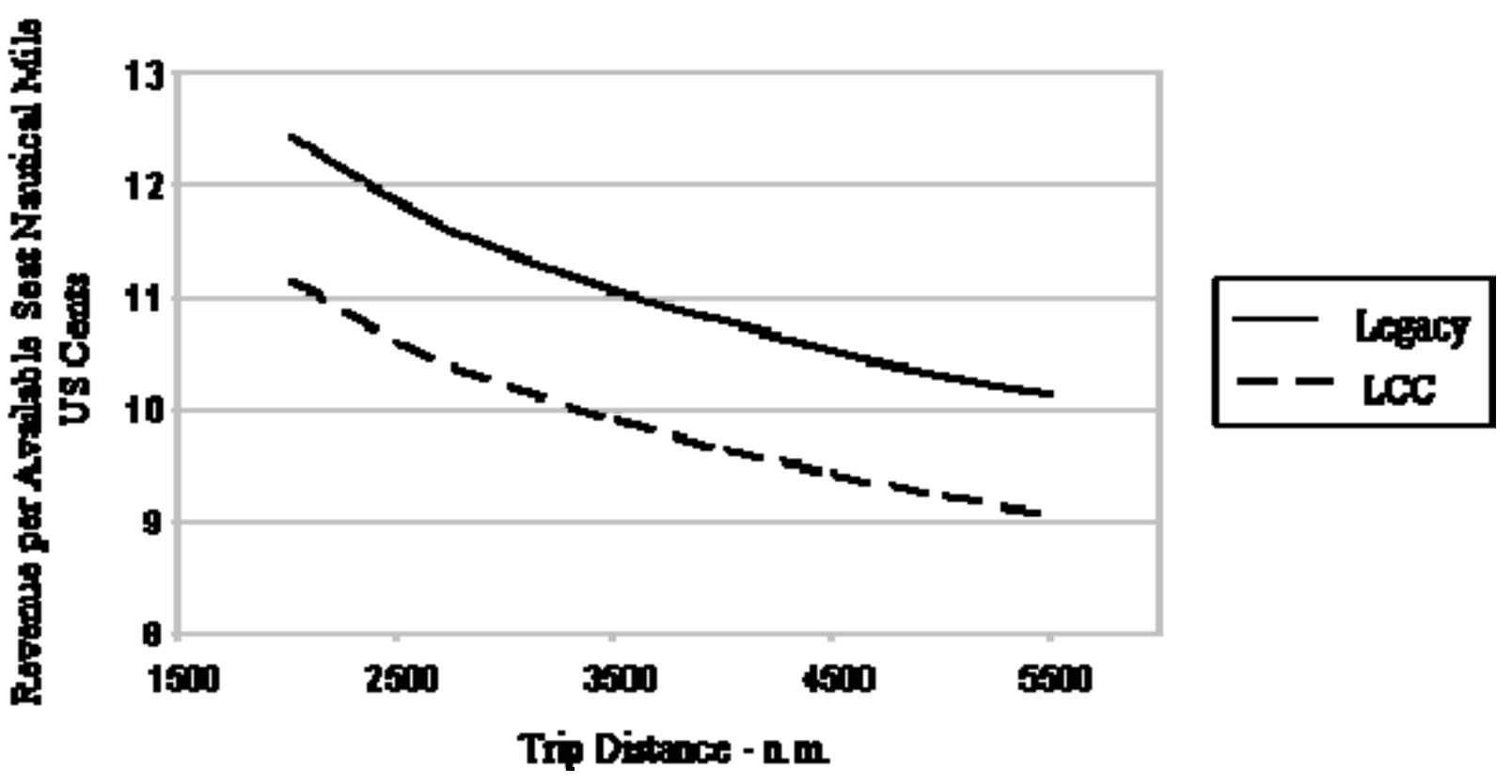

Although the above four graphs demonstrate basically the same behaviour in respect of costs and revenue as in the base case, Figure 12 reveals a different profitability outcome from that of the base case in which the legacy carrier showed a superior performance for all distances. However the financial performance of the long-haul low cost carrier has significantly improved when compared to the results obtained in (Figure 7). For sector lengths of up to 3,500 nautical miles, the LCC generates strong returns, but quickly falls if the flight is beyond this distance. However the simulation model reveals that the LCC's 
profitability is higher than that of the legacy carrier for distances up to 1,000 nautical miles, which corresponds to a flight time of around three hours.

Figure 12: Profitability Comparison: Legacy versus Long-haul LCC

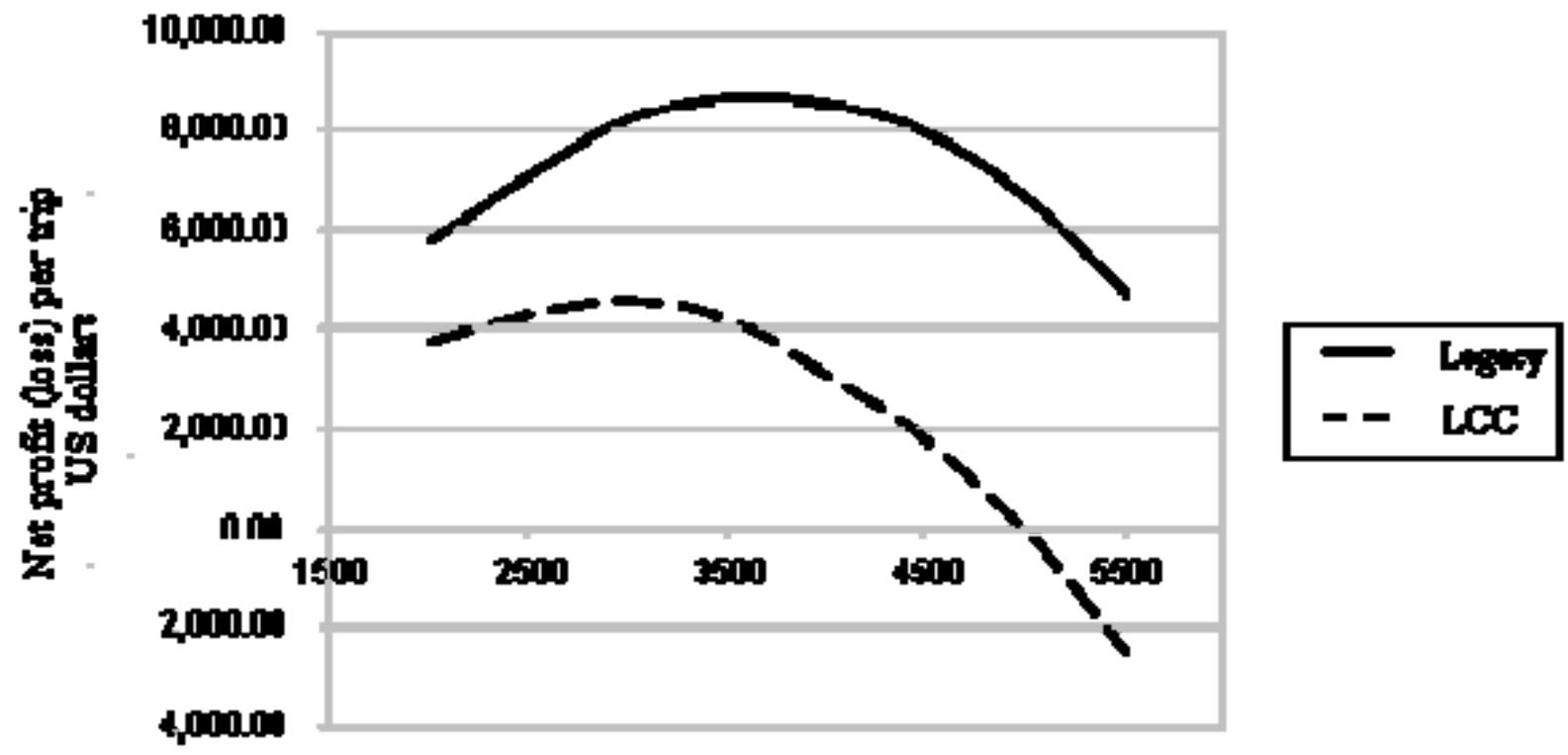

Tip Diance - nn

\subsection{RESULTS OF CASE C (LCC LOAD FACTOR OF 85\% )}

This case assumes that demand would be even more sensitive to price than in the previous two cases. In this instance, with the LCC fare $15 \%$ below that of the legacy carrier, the former produces a load factor of $85 \%$ and the legacy carrier one of $77 \%$. The aircraft utilisation profile is the same as in the other two cases. As is apparent, the LCC's cost curves at $85 \%$ load factor shown in Figures 13, 14 and 15 are not the same as those in the base case for the reasons explained above.

Figure 16 shows that the gap between the revenue per available seat-mile (RASM) of the two carrier types has closed significantly. Figure 17 reveals a sharp improvement in the LCC's profitability when this is compared to the results in the base case. In this instance the LCC demonstrates a superior profitability performance in distances up to $3000 \mathrm{~nm}$, the equivalent to a flight time of around 7 hours. Clearly, if long-haul, low cost carriers can fill up to $85 \%$ of a widebody aircraft, then this business model has some potential. 
Figure 13: Aircraft Related Cash Operating Costs per ASM
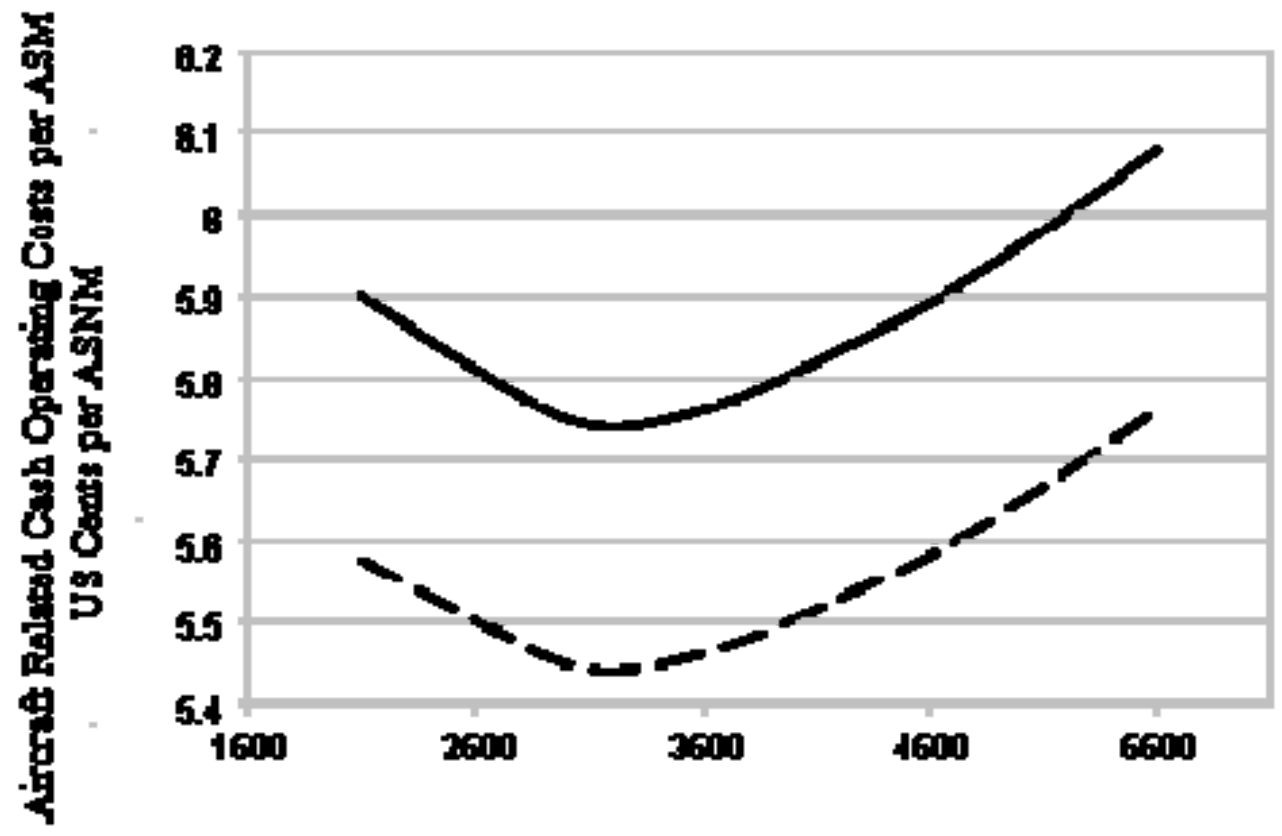

- Legacy

- L LCC

Tip Ditance - nm

Figure 14: Aircraft Related Operating Costs per ASM

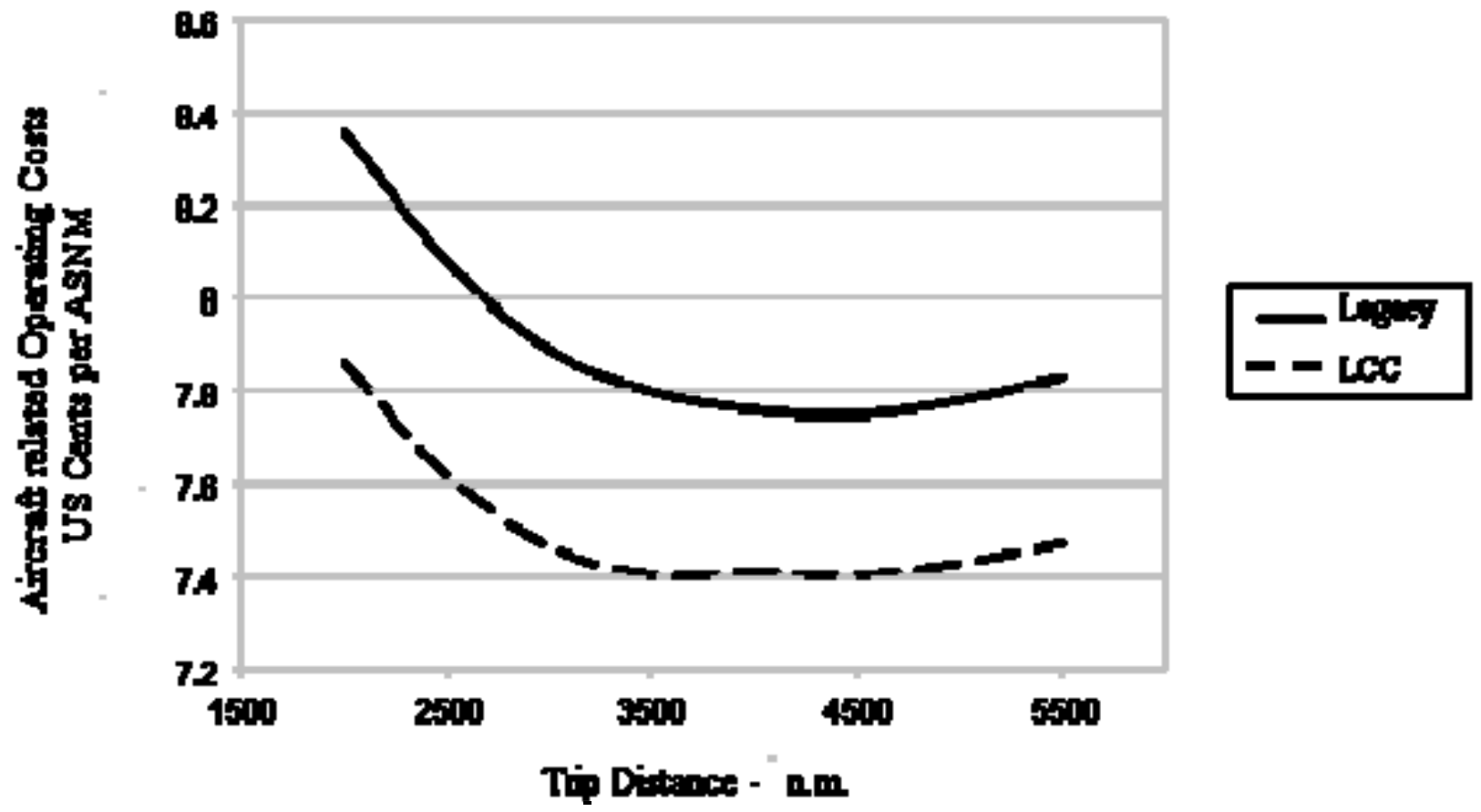


Figure 15: Total Operating Costs per ASM

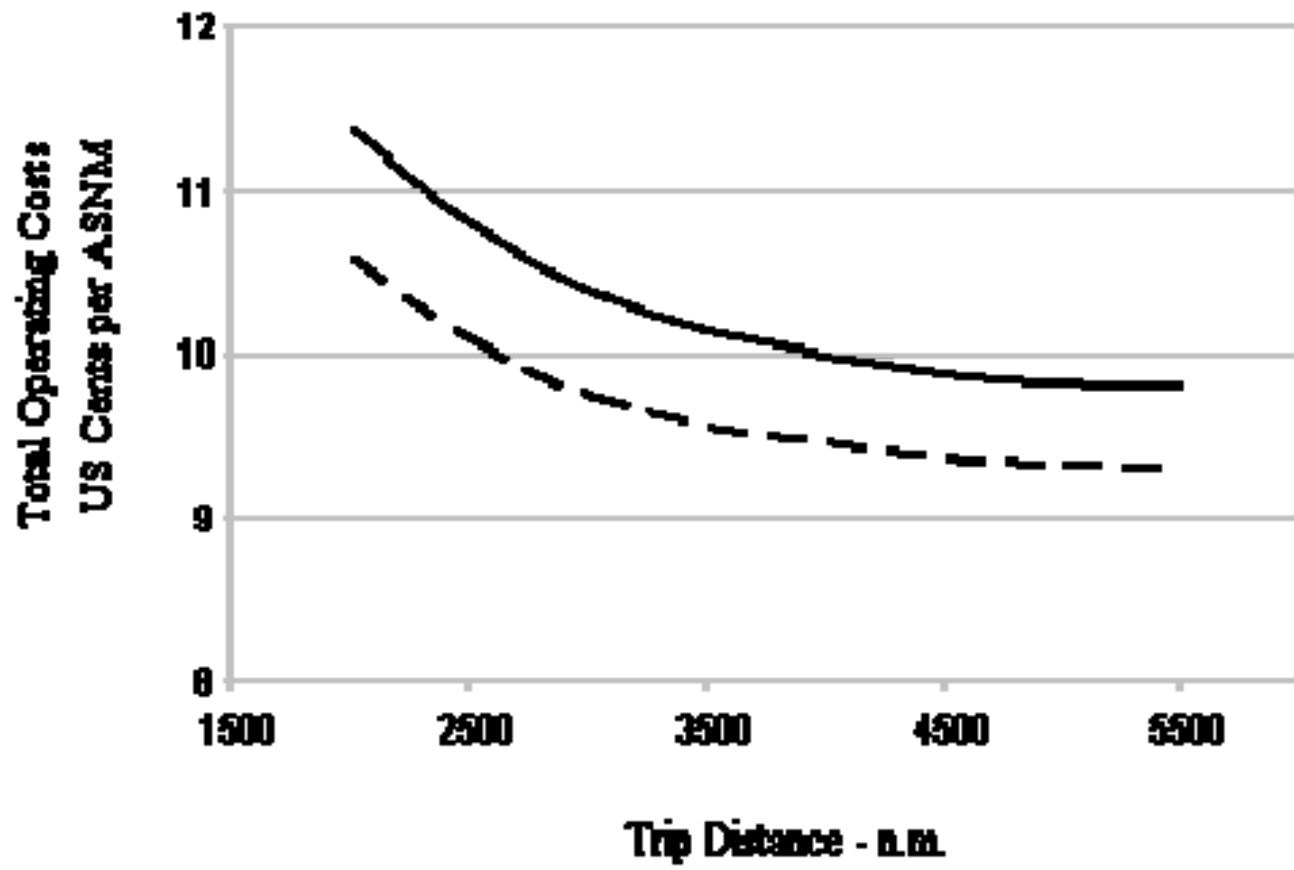

Figure 16: Revenue per ASM (RASM)

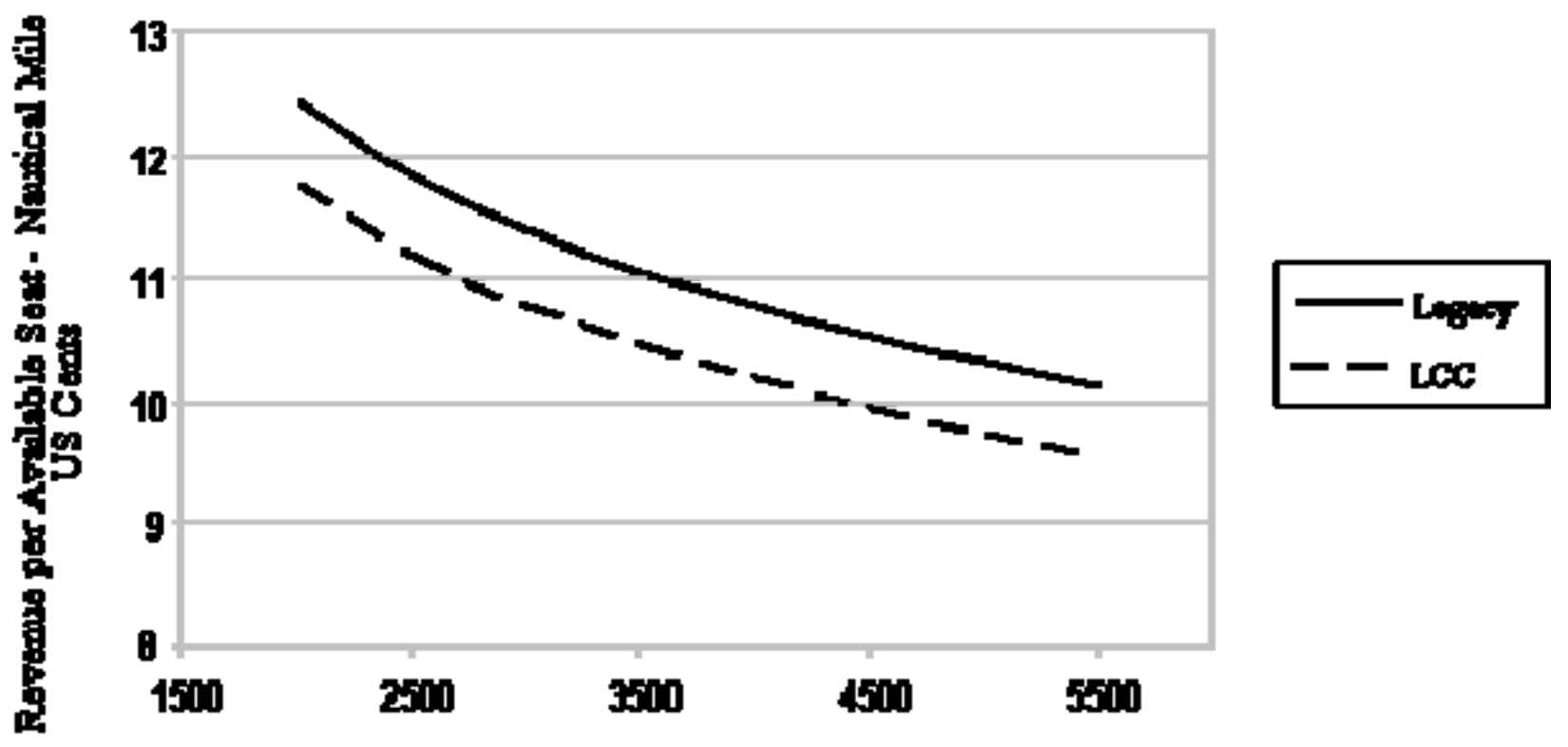

Thip Didance - nm 
Figure 17: Profitability Comparison: Legacy versus Long-haul LCC

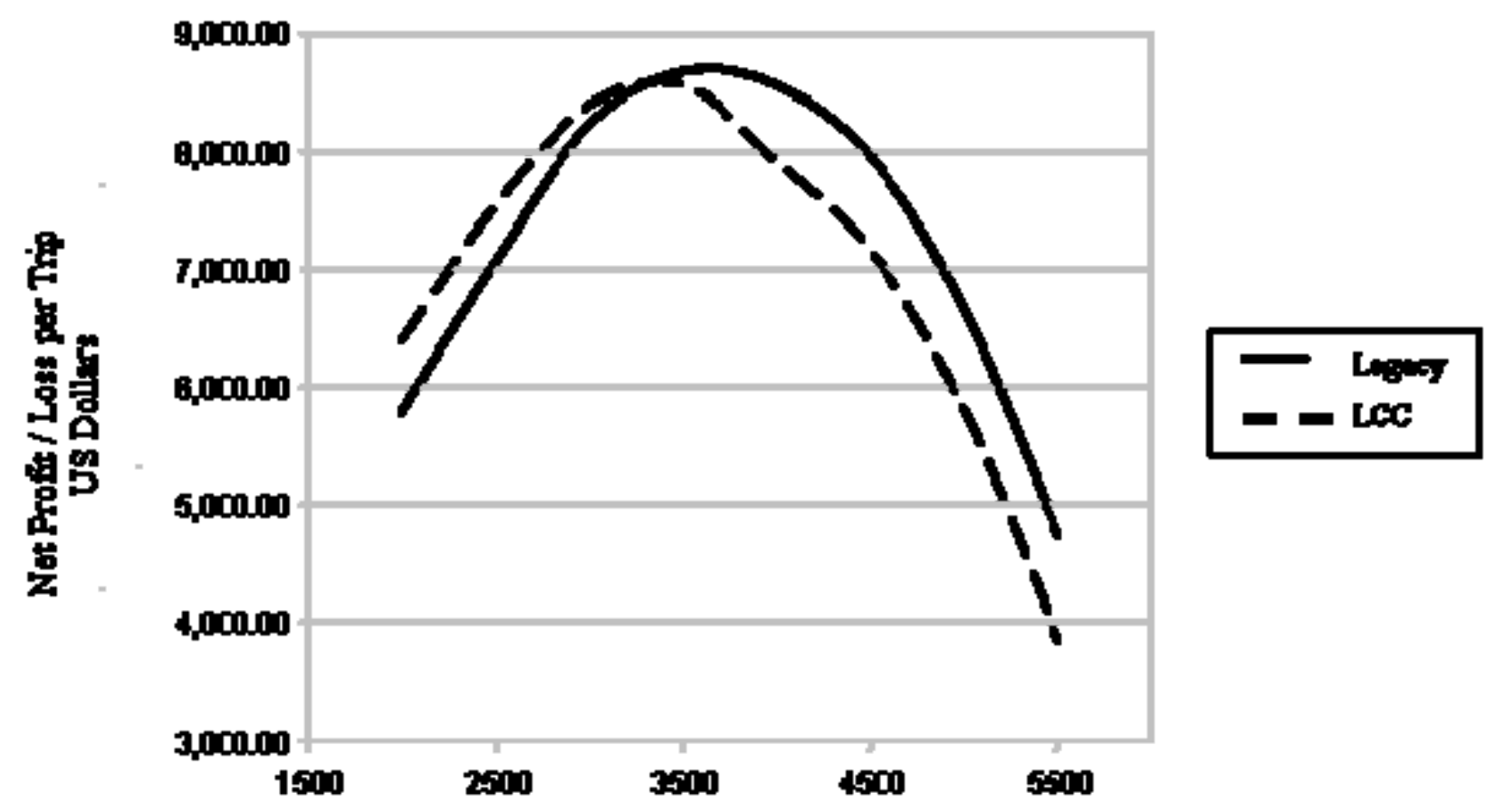

Tip Ditane - nm.

\section{SUSTAI NABI LITY OF THE LCC PROFITABI LITY ADVANTAGE}

Even though there is a clear profitability advantage in favour of the LCC in case C, a verification of how sustainable this advantage is must be made. If the cost difference between the LCC and the legacy carrier is very small, there is no guarantee that the profitability advantage of the former would prevail over time. It is possible that the legacy carrier would subsidise flights in direct competition with the LCC using profits generated in other markets. The LCC advantage would become sustainable when the cost gap is enough to dissuade the legacy carrier from matching the fares charged by the former. Experience in the US shows that the cost advantage of LCC has been consistently around 30 to 35\% (see DOT's Bureau of Transportation Statistics site: http://www.transtats.bts.gov). This research conducted into the three cases has demonstrated that the LCC cost advantage is no greater than $10 \%$, which implies that the viability of long-haul LCC operations must be highly questionable. This conclusion is supported by the poor experience to date of the low cost carriers that have provided long-haul services. Table 6 lists the low cost airlines that operate or have operated long-haul scheduled services since the turn of the century. Oasis Hong 
Kong, Zoom (and its UK subsidiary) and FlyGlobespan have already gone out of business and of the three that remain in business, only two focus exclusively on operating long-haul flights, namely Air Asia X and Air Transat. Currently, the combined long-haul fleets of these three LCC amount to only 32 aircraft, with 45 on order, of which 30 are for Air Asia X. So aside from Air Asia $X$ and Air Transat, at present the prospects of LCC playing a significant role in upsetting the long-haul status quo of the legacy carriers appears to be minimal. The ability of the latter to offer very low economy class fares in other than the highest periods of demand means that the ability of long-haul LCC to undercut their legacy rivals and capture the travelling public's attention with very low fares is very small. Aside from a comparatively small number of niche VFR and leisure orientated markets that are underserved by legacy carriers, the best prospects for a long-haul LCC is likely to exist in Asia. Cost and revenue data for the carriers shown in Table 6 is as yet unavailable and so it remains to be seen just how large a reduction in unit cost these LCC are able to deliver in comparison to their legacy rivals.

Table 6: Low Cost Long Haul Airlines

\begin{tabular}{|c|c|c|c|c|}
\hline Carrier & Base & $\begin{array}{c}\text { Ops } \\
\text { began }\end{array}$ & Aircraft Configuration & Comments \\
\hline Air Transat & Montreal & 1987 & $\begin{array}{c}\text { A310 (20C, 229Y) } \\
\text { A330-200 (21C, 322Y) }\end{array}$ & $\begin{array}{c}\text { Charter/scheduled } \\
\text { mix of services }\end{array}$ \\
\hline Zoom A/I Inc. & Ottawa & 2003 & $\begin{array}{c}\text { B767-300 (C24 YW60 } \\
\text { Y162) } \\
\text { B757-200 (C12 Y190) }\end{array}$ & $\begin{array}{l}\text { Ceased ops } \\
\text { in } 2008\end{array}$ \\
\hline Flyglobespan & Edinburgh & 2006 & $\begin{array}{l}\text { B767-300 (YW63 Y207) } \\
\text { B757-200 (YW45 Y156) }\end{array}$ & $\begin{array}{l}\text { Ceased ops in } \\
2009\end{array}$ \\
\hline Jetstar & Melbourne & 2006 & A330-200 (C38 Y265) & $\begin{array}{c}\text { Subsidiary of } \\
\text { Qantas }\end{array}$ \\
\hline Oasis & Hong Kong & 2006 & B747-400 (C81 Y278) & $\begin{array}{l}\text { Ceased ops } \\
\text { in } 2008\end{array}$ \\
\hline Zoom A/I UK & London LGW & 2007 & B767-300 (YW63 Y207) & $\begin{array}{l}\text { Ceased ops } \\
\text { in } 2008\end{array}$ \\
\hline Air Asia X & $\begin{array}{l}\text { Kuala } \\
\text { Lumpur }\end{array}$ & 2007 & A330-300 (YW28 Y364) & $\begin{array}{l}\text { Subsidiary of Air } \\
\text { Asia }\end{array}$ \\
\hline
\end{tabular}




\section{Acknowledgements}

The authors gratefully acknowledge the assistance of the Boeing Company for the data provided and for running the simulation model referred to in this paper, as well as for the relevant suggestions made in respect of the final text.

\section{References}

- Binggeli, U., \& Pompeo, L. (2002), Hyped hopes for Europe's low cost airlines, McKinsey Quarterly, 4.

- Boguslaski, R., Ito, H. and Lee, D. (2004), Entry patterns in the Southwest Airlines route system. Review of Industrial Organization 25 (3), p317-350.

- Button, K. and Ison, S. (2008), The economics of low cost airlines: Introduction, Research in Transportation Economics, 24 (1), p1-4.

- CAA (2007), Connecting the continents - long-haul passenger operations from the UK, CAP 771, UK Civil Aviation Authority, July.

- Dennis, N. (2007), End of the free lunch? The responses of traditional European airlines to the low cost carrier threat, Journal of Air Transport Management, 13(5), p311-321. Dobruszkes, F. (2009), New Europe, new low cost air services, Journal of Transport Geography, 17(6), p423-432.

- Doganis, R. (2001), The Airline Business in the 21st Century, Routledge, London.

- Dunn, G. (2009), Ready for Battle, Airline Business, 25(5), May, p54-62.

- Ezard, K. (2009), Pastures new, Airline Business, 25 (5), May, p64-66.

- Francis, G., Dennis, N., Ison, S. and Humphreys, I. (2007), The transferability of the low cost model to long-haul operations. Tourism Management, 28, p391-398.

- Francis, G., Humphreys, I., Ison, S. and Aicken, M. (2006), Where next for low cost airlines? A spatial and temporal comparative study, Journal of Transport Geography, $14(2), p 83-94$

- Ito, H., Lee, D. (2003), Market density and low cost carrier entries in the US airline industry: implications for future growth. Mimeo.

- Lawton, T. (2002), Cleared for Take-Off - Structure and Strategy in the Low Fare Airline Business, Ashgate, Aldershot.

- Porter, M. (1983), Industrial Organization and the Evolution of Concepts for Strategic Planning: The New Learning, in Managerial and Decision Economics, 4(3), p177.

- Thomas, G. (2009), Air Asia spots success, Air Transport World, 46 (9), p58-61. 
- O'Connell, J.F. and Williams, G. (2005), Passengers' perceptions of low cost airlines and full service carriers: A case study involving Ryanair, Aer Lingus, Air Asia and Malaysia Airlines, Journal of Air Transport Management, 11(4), p259-272.

- Morrell, P. (2008), Can long-haul low cost airlines be successful?, Research in Transportation Economics, 24(1), p61-67.

- Sobie, B. (2009), Not such a big thing, Airline Business, 25 (9), September, p52-54.

- Van der Bruggen, J. (2008), Low cost Aiming for Long-Haul, Masters Thesis, University of Amsterdam.

- Wensveen, J. and Leick, R. (2009), The long-haul low cost carrier: A unique business model, Journal of Air Transport Management, 15(3), p127-133.

- Williams, G. and Mason, K. (2004), Market Analysis of Europe's Low Cost Airlines: An examination of trends in the economics and operating characteristics of Europe's charter and no-frills scheduled airlines, Cranfield University Air Transport Group Research Report 9 ( $2^{\text {nd }}$ edition $)$. 